American Journal of Environmental Sciences 6 (4): 389-394, 2010

ISSN 1553-345X

(C) 2010 Science Publications

\title{
Selected Soil Morphological, Mineralogical and Sesquioxide Properties of Rehabilitated and Secondary Forests
}

\author{
${ }^{1}$ B.T. Saga, ${ }^{1}$ O.H. Ahmed, ${ }^{2}$ A.S. Jamaluddin ${ }^{2,3}$ H. Abdul-Hamid, ${ }^{4}$ S. Jusop, \\ ${ }^{2}$ N.M. Nik Ab. Majid, ${ }^{5}$ A. Hassan, ${ }^{2}$ K.H. Yusof and ${ }^{2,3}$ Arifin Abdu \\ ${ }^{1}$ Department of Crop Science, Faculty of Agriculture and Food Sciences, \\ University Putra Malaysia Bintulu Sarawak Campus, 97008 Bintulu, Sarawak \\ ${ }^{2}$ Department of Forest Management, Faculty of Forestry, \\ ${ }^{3}$ Laboratory of Sustainable Bioresource Management, \\ Institute of Tropical Forestry and Forest Products, \\ ${ }^{4}$ Department of Land Management, Faculty of Agriculture, \\ University Putra Malaysia, 43400 UPM Serdang, Selangor, Malaysia \\ ${ }^{5}$ School of International Tropical Forestry, University Malaysia Sabah, 88999 Sabah, Malaysia
}

\begin{abstract}
Problem statement: The tropical rain forests in Southeast Asia have been characterized by several researchers. However empirical data on soil characteristics under degraded forest land in tropical rain forest and rehabilitated program are limited. A study was conducted to evaluate the soil morphology, mineralogical and sesquioxide properties of a rehabilitated degraded forest land (19 years after it was planted with various indigenous species) in comparison with an adjacent secondary forest. Approach: Soil samples were air-dried and pass through a $2 \mathrm{~mm}$ sieve. Soil morphology was determined based on field observation. The non-crystalline (amorphous) of Al, Fe and Si oxides and hydroxides (Alo, Feo and Sio) were extracted with ammonium oxalate while the Dithionate-CitrateBicarbonate (DCB) method was used for extracting (crystalline) the $\mathrm{Al}, \mathrm{Fe}$ and $\mathrm{Si}$ oxides and hydroxides (Ald, Fed and Sid). The concentrations of extracted Al, Fe and Si were determined by atomic absorption spectroscopy. Mineralogical compositions were identified by X-ray diffraction method. Results: The A-horizon of secondary forest was darker and thicker than that of the rehabilitated forest. Root mat at the secondary forest was well-developed compared to the rehabilitated forest. The clay minerals were dominated with kaolinite and illite to a lesser extent of goethite and hematite accompanied with low values of activity ratio of $\mathrm{Al}$ and Fe oxides and hydroxides, indicating that the soils were highly weathered. Conclusion/Recommendations: The difference between rehabilitated and secondary forests was root abundance where secondary forest had most. Good root penetration in the secondary forest indicates that the soil texture there was not heavy. Soils in the rehabilitated and secondary forests were strongly weathered (high presence of kaolin minerals), but the low presence of sesquioxides suggests that they are yet to reached the ultimately weathered phase. The soil properties in terms of morphology, sesquioxides and clay minerals should be taken into account for better management of forest rehabilitation program in tropical regions.
\end{abstract}

Key words: Soil morphology, mineralogical, sesquioxide, rehabilitated and secondary forests

\section{INTRODUCTION}

Malaysia is made up of 19.01 million ha or $57.9 \%$ of the total land area, with Sabah and Sarawak having the larger proportion of forest than Peninsular Malaysia. Malaysia has a total area of 16 million ha of natural forest, of which 14.19 million ha are designated as Permanent Forest Estate (PFE) or forest reserve.
Approximately 10.53 million ha of the PFE are production forests with the remaining 3.66 million ha being protection forests. About 1.8 million ha located outside the PFE are designated as national parks and wildlife sanctuaries (Shahwahid, 2004). From 1963$1985,30 \%$ of the forests in Sarawak had been lost due to deforestation and logging activities (Leng et al., 2009).

Corresponding Author: Arifin Abdu, Department of Forest Management, Faculty of Forestry, University Putra Malaysia, 43400 UPM Serdang, Selangor, Malaysia Tel: +60389467177 Fax:+60389432514 
Agricultural conversions, shifting cultivation and timber harvesting in Malaysia is the main cause of degradation. Conversion of large scale of forested areas into oil palm and rubber plantations significantly causes land degradation in Peninsular Malaysia and shifting cultivation is the main cause of degradation in Sarawak. Iban and Bidayuh are the common natives who are involved in shifting cultivation along rivers in Sarawak. The increase of cultivation area is due to the increase of population growth. The figures based on satellite imaginaries of 1990-1991 showed that the total area affected by shifting cultivation was 3 million ha in Sarawak (Jomo et al., 2004).

Forest degradation may adversely affect our nature and ecosystem. The most common effect of degradation is climate change. Trees act as the major storage depot for the carbon; they absorb the carbon dioxide from atmosphere and produce fats, carbohydrate and protein of trees. When forest degradation occurs, trees are burnt, this causes the carbon dioxide to be released to the atmosphere and the concentration of carbon dioxide in the atmosphere increases. Soils are also affected as a result of forest degradation processes. The main effect of soil due to the degradation is soil erosion. As forests are cleared, soils are directly exposed to the sun and as a result, they get dried and become infertile. Moreover, soil nutrient stock could be lost as a result of poor soil texture and structure. This also destroys biodiversity of species and habitat. Therefore, if the economic, environmental, social and cultural benefits of the forest are to be continuously enjoyed, the damage has to be repaired by various technical approaches, such as rehabilitation, afforestation and reforestation.

Rehabilitation program is the process of making land useful again after disturbance. It involves the recovery of ecosystem function and processes in the degraded habitat. In afforestation program, the management strategies applied to degraded forestland aims to restore the capacity of a forest in order to produce a high quality product while reforestation program is necessary both to rehabilitate the deteriorating ecosystem and sustain the forest resource (Montagnini and Jordan, 2005). Several rehabilitation efforts using different technique have been carried out in Malaysia with varying degrees of success. One technique that has been successful in the warm temperate zone is dense planting (Miyawaki, 1993). This technique was used in Bintulu, Sarawak to rehabilitate the degraded shifting cultivation areas with indigenous tree species. The indigenous tree species recommended at checkboard are: Shorea ovata, S. mecistopteryx, S. macrophylla, Dryobalanops aromatica, Parashorea parvifolia, Hopea beccariana,
Durio carinatus and Eusideroxylon zwagery (Alias et al., 1998). The soil morphological, mineralogical and sesquioxides of the rehabilitated forest are yet to be studied. Therefore, a study was conducted to evaluate the soil morphology, mineralogical and sesquioxide of a rehabilitated degraded forest land (19 years after it was planted with various indigenous species) with special reference to the soils in adjacent secondary forests.

\section{MATERIALS AND METHODS}

This research was carried at University Putra Malaysia Bintulu Campus Sarawak. The study site was about $600 \mathrm{~km}$ northeast of Kuching the capital city of Sarawak, latitude $03^{\circ} 12^{\prime} \mathrm{N}$, longitude $113^{\circ} 02^{\prime} \mathrm{E}$ at $50 \mathrm{~m}$ above sea level. The mean annual rainfall is about 2993 $\mathrm{mm}$ and the mean daily temperature is $27^{\circ} \mathrm{C}$. The mean monthly relative humidity of the area is usually above $80 \%$ and slightly lower during rainy season.

Sampling plots of $20 \times 20 \mathrm{~m}$ were established for each group or stand ages of the rehabilitated forest. Soil profile $(0-20,20-40,40-60,60-80$ and $80-100 \mathrm{~cm}$ depth) in each particular site was dug for soil characterization. The soil morphology was determined based on field observation. The morphological variables determined were field soil texture, soil color, horizon and boundary, root abundance and soil consistency.

In the case of oxides and hydroxides ( $\mathrm{Al}, \mathrm{Fe}$ and $\mathrm{Si}$ ) and clay mineral compositions (kaolinite, illite, hematite and goethite), soil samples were taken from topsoil $(0-20 \mathrm{~cm})$. Five sub-samples were taken from each corner and the middle of the plot and they were homogenized to make a composite sample. This was applicable to all plots. Proper labeling was done to avoid identification error during transfer. These composite samples were air-dried, homogenized and sieved to pass a $2 \mathrm{~mm}$ sieve for further analysis.

The Dithionate-Citrate-Bicarbonate (DCB) method as described by Mehra and Jackson (1960) was used for the determination of $\mathrm{Al}, \mathrm{Fe}$ and $\mathrm{Si}$ oxides and hydroxides (Ald, Fed and Sid). The non-crystalline (amorphous) of $\mathrm{Al}, \mathrm{Fe}$ and $\mathrm{Si}$ oxides and hydroxides (Alo, Feo and Sio) were determined by using inductively coupled plasma atomic emission spectrophotometry (ICP-MS) after extracting the soil with $0.2 \mathrm{~mol} \mathrm{~L}^{-1}$ ammonium oxalate at $\mathrm{pH} 3.0$ by reciprocal shaking in the dark for $1 \mathrm{~h}$ (MacKeague and Day, 1966).

The XRD analyses were carried out using clay fraction isolated from soils that pretreated with $\mathrm{H}_{2} \mathrm{O}_{2}$ for Organic Matter (OM) removal. About $10 \mathrm{~g}$ of $2 \mathrm{~mm}$ air-dried soil was weighted into $1000 \mathrm{~mL}$ beaker and 
treated with $30 \% \mathrm{H}_{2} \mathrm{O}_{2}$ until all $\mathrm{OM}$ was destroyed, followed by heating to about $90^{\circ} \mathrm{C}$ to remove the excess $\mathrm{H}_{2} \mathrm{O}_{2}$. The sample was then washing with distilled water before transferring into a $250 \mathrm{~mL}$ centrifuge tube. The iron oxides were removed by adding $150 \mathrm{~mL}$ of citrate-bicarbonate buffer $(0.3 \mathrm{M}$ sodium citrate and added with $125 \mathrm{~mL}$ of $1 \mathrm{M}$ sodium bicarbonate) and $3 \mathrm{~g}$ sodium Dithionite (CBD) before putting into a water bath at $80^{\circ} \mathrm{C}$ and intermittently stirred for $20 \mathrm{~min}$. This treatment was performed twice prior to addition of $10 \mathrm{~mL}$ of solution containing $0.35 \mathrm{M}$ sodium hexametaphosphate and $0.07 \mathrm{M} \mathrm{Na}_{2} \mathrm{CO}_{3}$ and dispersed using a mixer. The clay fraction was separated by gravimetric sedimentation. It was expected that only phyllosilicates would be detected by XRD from this treatment, since iron oxides have been removed. The treated clay specimen then prepared on the glass slide and run on Philip PW 3040/60 X'pert Pro X-ray diffractometer, using $\mathrm{CuK}$-alpha radiation target, operated at $40 \mathrm{kV}$ and $30 \mathrm{~mA}$. The oriented specimens were scanned from $3-50^{\circ} 2 \theta$ at $1^{\circ} \mathrm{min}^{-1}$. XRD data were collected and stored with connected PC. Semiquantative estimation of the mineral proportion was calculated from the height of a first peak order times the width at half height.

The ANOVA (analysis of variance) followed by a Tukey's HSD test were used to test any significant difference of the means of sesquioxides and clay minerals properties between plots of rehabilitated and secondary forests. Statistical Analysis System version 9.1 was used for the statistical analysis.

\section{RESULTS}

Table 1 shows the main features of the soil morphological properties at the study sites. The soil at the study site was deep (more than about $100 \mathrm{~cm}$ ) with clayey texture. The difference was color and thickness of A-horizon. The Nirwana pedon in the lowland areas of the secondary forest, the surface area was only 0-13 $\mathrm{cm}$ in thickness and it was darker than other sites. The darker color of A-horizon was due to higher contents of soil organic matter. The minimum thickness of the other A-horizons were $15 \mathrm{~cm}$ with a range $0-20 \mathrm{~cm}$. Root mat at Nirwana was well-developed compared to the others sites. On the others sites, grass root was found in the surface horizon.

The sesquioxide properties of the soil at the different plots are shown in Table 2. Generally, the level of Alo, Feo, Ald and Fed were very low, indicating no translocation of amorphous and crystalline oxides. There was no major difference between the contents of $\mathrm{Al}$ and $\mathrm{Fe}$ at all this plot. For Alo, there was no significant difference between plots.

Table 1: Morphological properties of rehabilitated and secondary forests

\begin{tabular}{|c|c|c|c|c|c|c|}
\hline Plot & Depth $(\mathrm{cm})$ & Horizon & Color & Texture & Root & Consistency \\
\hline Phase 1 & $0-17$ & A & 10TR4/4 & SCL & $\mathrm{FeC}$ & Fri \\
\hline \multirow[t]{3}{*}{1991} & $17-60$ & bt1 & 10YR7/8 & SCL & $\mathrm{FeC}$ & Fri \\
\hline & $60-106$ & Bt2 & 10YR6/8 & SCL & $\mathrm{FeF}$ & Fri \\
\hline & $106-150$ & $\mathrm{Bt} 3$ & 10YR6/8 & SCL & $\mathrm{nf}$ & Fri \\
\hline Phase 2 & $0-20$ & A & 7.5YR5/6 & $\mathrm{L}$ & $\mathrm{FeC}$ & Fri \\
\hline \multirow[t]{3}{*}{1995} & $20-40$ & B & 7.5YR5/8 & $\mathrm{L}$ & $\mathrm{FeF}$ & Fri \\
\hline & $40-90$ & $\mathrm{BC} 1$ & $10 \mathrm{YR} 4 / 3$ & $\mathrm{~L}$ & $\mathrm{nf}$ & Fri \\
\hline & $90-150$ & $\mathrm{BC} 2$ & 10YR6/8 & $\mathrm{L}$ & $\mathrm{nf}$ & Fri \\
\hline Phase 3 & $0-15$ & A & 7.5YR7/6 & $\mathrm{SC}$ & $\mathrm{FeC}$ & Vfri \\
\hline \multirow[t]{4}{*}{2002} & $15-42$ & Bt1 & 10YR6/8 & $\mathrm{SC}$ & $\mathrm{FeF}$ & Fri \\
\hline & $24-69$ & Bt2 & $7.5 \mathrm{YR} 7 / 6$ & $\mathrm{SC}$ & $\mathrm{nf}$ & Fri \\
\hline & $69-100$ & $\mathrm{C}$ & 5YR6/1 & $\mathrm{SC}$ & $\mathrm{nf}$ & Fri \\
\hline & $>100$ & $\mathrm{R}$ & $5 \mathrm{R} 2 / 3$ & NT & $\mathrm{nf}$ & nd \\
\hline Phase 4 & $0-16$ & A1 & 10YR4/4 & $\mathrm{SC}$ & $\mathrm{FeC}$ & Fri \\
\hline \multirow[t]{4}{*}{2008} & $16-98$ & Bt1 & 10YR6/8 & $\mathrm{SC}$ & $\mathrm{FeF}$ & Fri \\
\hline & $46-98$ & Bt2 & 10YR6/8 & $\mathrm{SC}$ & $\mathrm{nf}$ & Fri \\
\hline & $98-120$ & $\mathrm{Bt} 3$ & 10YR5/8 & $\mathrm{SC}$ & $\mathrm{nf}$ & Fri \\
\hline & $120-150$ & $\mathrm{C}$ & $5 Y R 6 / 3$ & $\mathrm{SC}$ & $\mathrm{nf}$ & Fri \\
\hline \multirow[t]{4}{*}{ Nirwana 1} & $0-20$ & A & 7.5YR3/2 & SCL & $\mathrm{FeC}$ & Fri \\
\hline & $20-46$ & Bt1 & 10YR6/6 & $\mathrm{SC}$ & $\mathrm{MeC}$ & $\mathrm{Fi}$ \\
\hline & $46-94$ & Bt2 & 10YR6/8 & $\mathrm{SC}$ & $\mathrm{FeF}$ & $\mathrm{Fi}$ \\
\hline & $94-110$ & Bt3 & 10YR7/8 & $\mathrm{SC}$ & $\mathrm{FeF}$ & $\mathrm{Fi}$ \\
\hline \multirow[t]{4}{*}{ Nirwana 2} & $0-13$ & A1 & 10YR3/2 & $\mathrm{SC}$ & $\mathrm{MaC}$ & Fri \\
\hline & $13-26$ & Bt1 & 10YR6/6 & $\mathrm{SC}$ & $\mathrm{FeF}$ & Fri \\
\hline & $26-66$ & Bt2 & 10YR7/8 & $\mathrm{SC}$ & $\mathrm{FeC}$ & Fri \\
\hline & $66-100$ & Bt3 & 10YR6/8 & $\mathrm{SC}$ & $\mathrm{FeF}$ & Fri \\
\hline
\end{tabular}

Note: Texture: SCL: Sandy clay loam; SC: Sandy clay; L: Loam; NT: No texture Abundance: Fe: Few, Ma: Many, nf: not found, Size: C: Coarse, F: Fine, Me: Medium; Consistency: Fi: Firm, Fri: Friable, Vfri: Very friable 
Am. J. Environ. Sci., 6 (4): 389-394, 2010

Table 2: Sesquioxide contents of rehabilitated and secondary forests

\begin{tabular}{|c|c|c|c|c|c|c|c|c|}
\hline \multirow[b]{2}{*}{ Plot } & \multicolumn{3}{|c|}{ Oxalate extractant $\mathrm{t}^{\mathrm{a}}\left(\mathrm{g} \mathrm{kg}^{-1}\right)$} & \multicolumn{5}{|c|}{ DCB extractant ${ }^{\mathrm{b}}\left(\mathrm{g} \mathrm{kg}^{-1}\right)$} \\
\hline & Alo & Feo & Sio & Ald & Fed & Sid & Alo/Ald & $\mathrm{Feo} / \mathrm{Fed}$ \\
\hline 1991 & $0.26^{\mathrm{a}}$ & $0.22^{\mathrm{bc}}$ & $<0.0001^{\mathrm{ab}}$ & $0.59^{\mathrm{ab}}$ & $3.61^{\mathrm{a}}$ & 0.38 & $0.44^{\mathrm{ab}}$ & $0.06^{\mathrm{c}}$ \\
\hline 1993 & $0.20^{\mathrm{a}}$ & $0.20^{\mathrm{c}}$ & $<0.0001^{\mathrm{ab}}$ & $0.33^{\mathrm{ab}}$ & $1.70^{\mathrm{b}}$ & nd & $0.61^{\mathrm{sb}}$ & $0.12^{\mathrm{ab}}$ \\
\hline 1995 & $0.19^{\mathrm{a}}$ & $0.28^{\mathrm{abc}}$ & $<0.0001^{\mathrm{ab}}$ & $0.42^{\mathrm{ab}}$ & $2.26^{\mathrm{b}}$ & nd & $0.45^{\mathrm{ab}}$ & $0.12^{\mathrm{ab}}$ \\
\hline 1996 & $0.20^{\mathrm{a}}$ & $0.23^{\mathrm{abc}}$ & $<0.0001^{\mathrm{ab}}$ & $0.63^{\mathrm{c}}$ & $1.58^{\mathrm{b}}$ & nd & $0.32^{\mathrm{c}}$ & $0.15^{\mathrm{ab}}$ \\
\hline 1997 & $0.21^{\mathrm{a}}$ & $0.29^{\mathrm{abc}}$ & $<0.0001^{\mathrm{ab}}$ & $0.37^{\mathrm{ab}}$ & $1.98^{\mathrm{b}}$ & nd & $0.57^{\mathrm{b}}$ & $0.15^{\mathrm{ab}}$ \\
\hline 1998 & $0.24^{\mathrm{a}}$ & $0.34^{\mathrm{abc}}$ & $<0.0001^{\mathrm{ab}}$ & $0.32^{\mathrm{ab}}$ & $1.72^{\mathrm{b}}$ & nd & $0.75^{\mathrm{a}}$ & $0.20^{\mathrm{a}}$ \\
\hline 1999 & $0.24^{\mathrm{a}}$ & $0.27^{\mathrm{abc}}$ & $0.05^{\mathrm{ab}}$ & $0.5^{\mathrm{b}}$ & $1.79^{\mathrm{b}}$ & nd & $0.48^{\mathrm{bc}}$ & $0.15^{\mathrm{ab}}$ \\
\hline 2000 & $0.27^{\mathrm{a}}$ & $0.33^{\mathrm{abc}}$ & $<0.0001^{\mathrm{ab}}$ & $0.4^{\mathrm{ab}}$ & $1.66^{\mathrm{b}}$ & nd & $0.68^{\mathrm{c}}$ & $0.20^{\mathrm{a}}$ \\
\hline 2001 & $0.17^{\mathrm{a}}$ & $0.25^{\mathrm{abc}}$ & $<0.0001^{\mathrm{ab}}$ & $0.42^{\mathrm{ab}}$ & $1.61^{\mathrm{b}}$ & nd & $0.40^{\mathrm{bc}}$ & $0.16^{\mathrm{ab}}$ \\
\hline 2002 & $0.14^{\mathrm{a}}$ & $0.04^{\mathrm{abc}}$ & $0.04^{\mathrm{ab}}$ & $0.45^{\mathrm{ab}}$ & $1.55^{\mathrm{b}}$ & nd & $0.31^{\mathrm{bc}}$ & $0.03^{\mathrm{c}}$ \\
\hline 2003 & $0.13^{\mathrm{a}}$ & $0.36^{\mathrm{abc}}$ & $0.04^{\mathrm{ab}}$ & $0.3^{\mathrm{ab}}$ & $1.92^{\mathrm{b}}$ & nd & $0.43^{\mathrm{bc}}$ & $0.19^{\mathrm{a}}$ \\
\hline 2004 & $0.22^{\mathrm{a}}$ & $0.23^{\mathrm{abc}}$ & $<0.0001^{\mathrm{ab}}$ & $0.5^{\mathrm{ab}}$ & $1.54^{\mathrm{b}}$ & nd & $0.44^{\text {bc }}$ & $0.15^{\mathrm{a}}$ \\
\hline 2005 & $0.14^{\mathrm{a}}$ & $0.42^{\mathrm{a}}$ & $0.04^{\mathrm{ab}}$ & $0.31^{\mathrm{ab}}$ & $1.92^{\mathrm{b}}$ & nd & $0.45^{\mathrm{bc}}$ & $0.22^{\mathrm{a}}$ \\
\hline 2006 & $0.11^{\mathrm{a}}$ & $0.30^{\mathrm{abc}}$ & $0.03^{\mathrm{ab}}$ & $0.23^{\mathrm{ab}}$ & $1.67^{c}$ & nd & 0.48 & $0.18^{\mathrm{a}}$ \\
\hline 2007 & $0.16^{\mathrm{a}}$ & $0.23^{\mathrm{abc}}$ & $<0.0001^{\mathrm{ab}}$ & $0.32^{\mathrm{ab}}$ & $1.38^{\mathrm{b}}$ & nd & $0.51^{\mathrm{b}}$ & $0.17^{\mathrm{a}}$ \\
\hline 2008 & $0.27^{\mathrm{a}}$ & $0.20^{\mathrm{c}}$ & $<0.0001^{\mathrm{ab}}$ & $0.32^{\mathrm{ab}}$ & $1.57^{\mathrm{b}}$ & nd & $0.84^{\mathrm{a}}$ & $0.13^{\mathrm{a}}$ \\
\hline Nirwana 1 & $0.11^{\mathrm{a}}$ & $0.30^{\mathrm{abc}}$ & $0.05^{\mathrm{ab}}$ & $0.31^{\mathrm{ab}}$ & $1.46^{\mathrm{b}}$ & nd & $0.35^{\mathrm{c}}$ & $0.21^{\mathrm{a}}$ \\
\hline Nirwana 2 & $0.14^{\mathrm{a}}$ & $0.32^{\mathrm{abc}}$ & $0.5^{\mathrm{a}}$ & $0.42^{\mathrm{ab}}$ & $2.12^{b}$ & nd & $0.33^{\mathrm{c}}$ & $0.15^{\mathrm{ab}}$ \\
\hline
\end{tabular}

Note: Means with different letters within column indicate significant difference at P <0.05 between plots by Tukey's (HSD) test; ${ }^{\text {a }}$ : Amounts of $\mathrm{Al}$ and $\mathrm{Fe}$ extracted by ammonium oxalate. ${ }^{\mathrm{b}}$ : Amounts of $\mathrm{Al}$ and $\mathrm{Fe}$ extracted by a dithionate citrate system buffered with sodium bicarbonate. nd: Not determined

Table 3: Clay mineral compositions of rehabilitated and secondary forests

\begin{tabular}{|c|c|c|c|c|}
\hline Plot & it & $\mathrm{Kt}$ & $\mathrm{Gt}$ & $\mathrm{Ht}$ \\
\hline 1991 & $++++^{\mathrm{a}}$ & $++++^{\mathrm{a}}$ & + & \pm \\
\hline 1993 & $+++^{\mathrm{a}}$ & $++++^{\mathrm{a}}$ & + & nd \\
\hline 1995 & $+++^{\mathrm{a}}$ & $+++{ }^{\mathrm{ab}}$ & \pm & \\
\hline 1996 & $+++^{\mathrm{a}}$ & $++^{\mathrm{b}}$ & nd & nd \\
\hline 1997 & $+++^{\mathrm{a}}$ & $++++^{\mathrm{a}}$ & + & nd \\
\hline 1998 & $++^{\mathrm{ab}}$ & $+++{ }^{\mathrm{ab}}$ & nd & nd \\
\hline 1999 & $++^{\mathrm{ab}}$ & $++++^{\mathrm{a}}$ & \pm & nd \\
\hline 2000 & $+++^{\mathrm{a}}$ & $++++^{\mathrm{a}}$ & + & nd \\
\hline 2001 & $++^{a b}$ & $++++^{\mathrm{a}}$ & nd & nd \\
\hline 2002 & $++^{\mathrm{ab}}$ & $++++^{\mathrm{a}}$ & nd & nd \\
\hline 2003 & $++^{a b}$ & $++^{\mathrm{b}}$ & nd & nd \\
\hline 2004 & $+^{\mathrm{b}}$ & $++++^{\mathrm{a}}$ & nd & nd \\
\hline 2005 & $+++^{\mathrm{a}}$ & $++++^{\mathrm{a}}$ & nd & nd \\
\hline 2006 & $++^{\mathrm{ba}}$ & $++++^{\mathrm{a}}$ & nd & nd \\
\hline 2007 & $+++^{\mathrm{a}}$ & $++++^{\mathrm{a}}$ & + & nd \\
\hline 2008 & $+++^{\mathrm{a}}$ & $++++^{\mathrm{a}}$ & + & \pm \\
\hline Nirwana 1 & $++++^{\mathrm{a}}$ & $++^{\mathrm{b}}$ & \pm & nd \\
\hline Nirwana 2 & $+^{\mathrm{b}}$ & $++++^{\mathrm{a}}$ & \pm & nd \\
\hline
\end{tabular}

Note: Means with different letters within column indicate significant difference at $\mathrm{p} \leq 0.05$ between plots by Tukey's (HSD) test. It: Illite, Kt: Kaolinite, Gt: Goethite, Ht: Hematite, nd: not determined, $\pm: 0-$ 5\%, +:5-20\%, ++:20-40\%, +++:40-60\%, ++++ : >60\%

The maximum mean was 0.26 at plot 2000 and the minimum mean for the Alo was 0.105 at Nirwana 1. For Feo, the highest value was recorded at plot 2005 which significantly different with plots 1991, 2004 and 2008, whereas there was no significant difference found with the other plots. The lowest mean for Feo was recorded at plot 2008 with 0.19 . For Sio, there was significant difference between plots and some of the Sio were absent in some plots. The highest mean of Sio content was 0.05 it was found at Nirwana 2. For Ald, there was significant difference among the plots. The highest mean was 0.62 it was found at plot 1996. Meanwhile the lowest mean of Ald was 0.22 at plot 2006. Meanwhile for $\mathrm{Feo}$, there was significant difference between the plots. The highest mean was 3.61 at 1991. Meanwhile the lowest mean was 1.37 at plot 2007. The content of Sid was almost not found of the soils studied except in plot 1991. The activity ratios of $\mathrm{Al}$ and $\mathrm{Fe}$ oxides and hydroxides were regarded low.

The clay minerals composition of the soils both at rehabilitated and secondary forests are shown in Table 3. The results showed that the clay minerals were dominated by kaolin minerals followed by illite to a lesser extent of goethite and hematite. The abundant amount of kaolinite and small value of goethite and hematite revealed that the soils in the present study were highly weathered.

\section{DISCUSSION}

Wambeke (1992) stated that, the greater the rain intensity, the greater the proportion of large drops and the faster their terminal fall velocities will affect the erosivity. The tropical rains have higher drops. For these reasons, frequent heavy rainfall might have caused a severe erosion of the surface soil and therefore subsurface soils became a current surface layer. Alias et al. (1998) stated that the soil of the study site belongs to Bekenu and Nyalau Series. According to Soil Survey Staff (1999) Bekenu Series are fine loamy red yellow podzolic group with hue color of 10YR within $50 \mathrm{~cm}$. The Nyalau Series is characterized by the 
coarse loamy red yellow podzolic group that developed from sandstone. The Bekenu and Nyalau Series have a brownish yellow A-horizon over a yellow B horizon. The darker color of the A-horizon at Nirwana (down) compared to other pedons suggests sufficient duration to accumulate soil organic matter. Root elongation was shallower in most of the sites except for the secondary forest. This result suggests that most of the sites had high clay content with lower levels of nutrients and more acidic nature. Sakurai et al. (1995) stated that root elongations as well as tree growth are restricted by the combination of a heavy texture with strong acidity.

In the case of sesquioxide, the contents of Alo, Feo, Ald and Fed were very low in all of the plots. Sakurai et al. (1996) studied this type of soil from four different regions in Thailand and they stated that soils with high activity ratios of $\mathrm{Al}$ and $\mathrm{Fe}$ indicate strong weathering. Zaidey et al. (2010) stated that a lack of major difference between $\mathrm{Al}$ and Fe might be related to desilication in the soil upon weathering and leaching. It suggests that the low amount of $\mathrm{Al}$ and Fe were related to the weathering and through leaching in both forests. The values of Alo in all the plots were similar. This suggests that the amount of organic matter were similar. This also indicates no translocation of amorphous and crystalline oxide (Abdu et al., 2007). The highest content of Feo indicates that this plot received a significant amount of organic matter. This organic matter can stabilize the free Fe as in the form of oxides (Ishizuka et al., 2000). The reductive condition in the soil also can cause the Fe oxide to easily dissolve. This dissolved Fe could be oxidized and accumulated in the surface horizon. The factor of leaching of amorphous fraction of this element may be smaller compared to other plots.

The ratio of $\mathrm{Al}$ and $\mathrm{Fe}$ oxides and hydroxides of the soils usually refer to a relative indicator of the degree of crystallinity of free Fe oxides (Sakurai et al., 1996). He further illustrates that the activity ratio of $\mathrm{Al}$ and Fe oxides and hydroxides of the soils less than 0.10 were reached to the ultimately weathered. The Fe and Al oxides and hydroxides become more crystallized upon weathering process going on due to the loss of active hydroxyl groups which eventually lead to a value below 0.10 . In general, the activity ratios of $\mathrm{Al}$ and $\mathrm{Fe}$ oxides and hydroxides in this study were higher than reported by Sakurai et al., (1996) implies that the soils were highly weathered but are not reach the ultimately weathered stage.

Table 3 shows that kaolinite was the dominant clay minerals followed by illite, whereas goethite and hematite were not dominant. The dominance of kaolinite could be ascribed to the granitic parent materials (Zaidey et al., 2010). The present of kaolin minerals in the rehabilitated and secondary forests indicated that the soils were strongly weathered, typical of Ultisols (Ohta and Syarif, 1992; Ohta et al., 1993; Hattori et al., 2005). According to Eswaran et al. (1990) kaolinite and gibbsite are produced faster in the humid tropical region without any distinct dry season. This also suggests that the amount of rainfall and dry season in this region have significant impact on kaolin formation. The presence of illite indicates that successive supply of new materials for soil formation affected weathering in all plots. It also indicates that the presence of illite in soil takes a long time weathered to kaolinite (Watanabe et al., 2006). The presence of hematite is characterized by intense weathering. The presence of small amount of goethite and hematite also suggests that they were removed selectively in event of weathering processes and soil erosion.

\section{CONCLUSION}

The difference between rehabilitated and secondary forests was root abundance where secondary forest had most. Good root penetration in the secondary forest indicates that the soil texture there was not too heavy. Soils in the rehabilitated and secondary forests were strongly weathered (high presence of kaolin minerals), but the low presence of sesquioxides suggest that they are yet to reach the ultimately weathered phase. The soil variable in terms of morphology, sesquioxides and clay minerals compositions should be taken into consideration for appropriate management of rehabilitation or afforestation programs in tropical regions in particular tropical soils of Malaysia which regarded highly weathered and concomitantly low in fertility.

\section{ACKNOWLEDGEMENT}

This research was financially supported by the Ministry of Higher Education of Malaysia (MOHE) under Research University Grant Scheme (RUGS-0301-09-0704) through University Putra Malaysia, Malaysia (UPM). We wish to express our gratitude to the staff of the Department of Crop Production, University Putra Malaysia, Bintulu Sarawak Campus, Faculty of Forestry and Faculty of Agriculture, University Putra Malaysia during field sampling and laboratory analysis. We would like to thank to the of the final year students (Bachelor Scince of Bioindustry), University Putra Malaysia, Bintulu Sarawak Campus for their contribution in helping digging the soil profiles and measuring the growth of planted trees as well as vegetation survey. 


\section{REFERENCES}

Alias, M.A., M.Z. Hamzah, K. Fujiwara and S. Meguro, 1998. Rehabilitation of tropical rainforests based on potential natural vegetation species for degraded areas in Sarawak, Malaysia. Tropics, 7: 223-239.

Abdu, A., S. Tanaka, S. Jusop, Z. Ibrahim and D. Hattori et al., 2007. Soil characteristic under rehabilitation of degraded forestland in Perak, Peninsular Malaysia. Pedologist, 51: 76-88.

Eswaran, H., F. De Cornick and T. Varghese, 1990. Role of Plinthite and Related forms in Soil Degradation. In: Advances in Soil Science, Lal, R. and B.A. Stewart (Eds.). CRC Press, Boca Raton, FL., pp: 109-127.

Hattori, D., J. Sabang, S. Tanaka, J.J. Kendawang and I. Ninomiya et al., 2005. Soil characteristics under three vegetation types associated with shifting cultivation in a mixed dipterocarp forest Sarawak, Malaysia. Soil Sci. Plant Nutr., 51: 231-241. DOI: 10.1111/j.1747-0765.2005.tb00027.x

Leng, L.Y., O.H. Ahmed, N.M.A. Majid and M.B. Jalloh, 2009. Organic matter, carbon and humic acids in rehabilitated and secondary forest soils. Am. J. Applied Sci., 6: 824-828. http://www.scipub.org/fulltext/ajas/ajas65824-828.pdf

Ishizuka, S., K. Sakurai, J. Sabang, J.J. Kendawang and H.S. Lee, 2000. Soil characteristics of an abandoned shifting cultivation land in Sarawak, Malaysia. $\quad$ Tropics, 10: 251-263. http://www.jstage.jst.go.jp/article/tropics/10/2/251/_pdf

Jomo, K.S., Y.T. Chang and K.J. Khoo, 2004. Deforesting Malaysia: The Political Economy and Social Ecology of Agriculture Expansion and Commercial Logging. 1st Edn., Zed Books Limited, New York, ISBN: 978-1842774663, pp: 304.

MacKeague, J.A. and J.H. Day, 1966. Dithionite and oxalate-extractable $\mathrm{Fe}$ and $\mathrm{Al}$ as aids in differentiating various classes of soils. Can. J. Soil Sci., 46:

13-22. http://www.garfield.library.upenn.edu/classics1980 /A1980JM61300001.pdf

Mehra, O.P. and M.L. Jackson, 1960. Iron oxide removal from soils and clays by a dithionite-citrate system buffered with sodium. Clays Clay Miner, 7: 317-327.

Montagnini, F. and C.F. Jordan, 2005. Tropical Forest Ecology: The Basis for Conservation and Management. 1st Edn., Springer, USA., ISBN: 10: 3540237976, pp: 295.

Miyawaki, A., 1993. Restoration of Native Forests from Japan to Malaysia. In: Restoration of Tropical Forest Ecosystem, Leith, H. and M. Lohmann (Eds.). Kluwer Academic Publishers, Netherlands, pp: 5-24.
Ohta, S. and E. Syarif, 1992. Ultisols of "Lowland dipterocarp forest" in East Kalimantan, Indonesia. II. Status of carbon, nitrogen and phosphorus. Soil Sci. Plant Nutr., 38: 207-216. http://ci.nii.ac.jp/naid/110001720111/en/

Ohta, S., E. Syarif, T. Nagaharu and M. Satour, 1993. Ultisols of lowland dipterocarp forest in east Kalimantan, Indonesia. III. Clay minerals, free oxides and exchangeable cations. Soil Sci. Plant Nutr., 39: 1-12. http://ci.nii.ac.jp/naid/110001718695

Sakurai, K., B. Puriyakorn, P. Preechapanya, V. Tanpibal and K. Muangnil et al., 1995. Improvement of biological productivity in degraded lands in Thailand III. Soil hardness measurement in the field. Tropics, 4: 151-172. http://www.jstage.jst.go.jp/article/tropics/4/2_3/15 1/_pdf

Sakurai, K., S. Kozasa, T. Yuasa, B. Puriyakorn and P. Preechapanya et al., 1996. Changes in soil properties after land degradation associated with various human activities in Thailand. Soil Sci. Plant Nutr., 42: 81-92. http://cat.inist.fr/?aModele $=$ afficheN\&cpsidt $=3232$ 322

Shahwahid, M.H.O., 2004. Forest certification in Malaysia. Proceeding of the Symposium on Forest Certification in Developing and Transitioning Societies: Social, Economic and Ecological Effects, June 10-11, Yale School of Forestry and Environmental Studies, New Heaven, Connecticut, USA., $\quad$ pp: 1-29. http://www.yale.edu/forestcertification/symposium /pdfs/malaysia_symposium.pdf

Soil Survey Staff, 1999. Keys to Soil Taxonomy. 8th Edn., Natural Resources Conservation Service, USDA., Washington, DC., pp: 869.

Wambeke, A.V., 1992. Soils of the Tropics: Properties and Appraisal. 1st Edn., McGraw-Hill Inc., New York, ISBN: 0070679460, pp: 343.

Watanabe, T., S. Funakawa and T. Kosaki, 2006. Clay mineralogy and its relationship to soil solution composition in soils from different weathering environments of humid Asia: Japan, Thailand and Indonesia. Geoderma, 135: 51-63. DOI: 10.1016/j.geoderma.2006.02.001

Zaidey, A.K., A. Arifin, I. Zahari, A.H. Hazandy and M.H. Zaki et al., 2010. Characterizing soil properties of lowland and hill dipterocarp forests at Peninsular Malaysia. Int. J. Soil Sci., 5: 112-113. 